Division of Geological \& Geophysical Surveys

RAW-DATA FILE 2014-17

\title{
GEOCHEMICAL MAJOR-OXIDE, MINOR-OXIDE, TRACE-ELEMENT, AND RARE-EARTH-ELEMENT DATA FROM ROCK SAMPLES COLLECTED IN 2013 IN THE RAY MOUNTAINS AREA, BETTLES A-1 AND A-6 QUADRANGLES, ALASKA
}

\author{
by \\ Amy L. Tuzzolino, Lawrence K. Freeman, and Rainer J. Newberry
}

$\$ 2.00$

AUGUST 2014

THIS REPORT HAS NOT BEEN REVIEWED FOR TECHNICAL CONTENT OR FOR CONFORMITY TO THE EDITORIAL STANDARDS OF DGGS

\author{
Released by
}

STATE OF ALASKA

DEPARTMENT OF NATURAL RESOURCES

Division of Geological \& Geophysical Surveys

3354 College Road, Fairbanks, Alaska 99709-3707

Phone 907-451-5020 Fax 907-451-5050

dggspubs@alaska.gov_www.dggs.alaska.gov

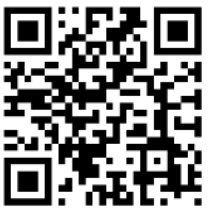





\title{
GEOCHEMICAL MAJOR-OXIDE, MINOR-OXIDE, TRACE-ELEMENT, AND RARE-EARTH-ELEMENT DATA FROM ROCKS COLLECTED IN 2013 IN THE RAY MOUNTAINS AREA, BETTLES A-1 AND A-6 QUADRANGLES, ALASKA
}

\author{
by \\ Amy L. Tuzzolino ${ }^{1,2}$, Lawrence K. Freeman ${ }^{1}$, and Rainer J. Newberry ${ }^{2}$ \\ ${ }^{1}$ Alaska Division of Geological \& Geophysical Surveys, 3354 College Rd., Fairbanks, AK 99709-3707; \\ lawrence.freeman@alaska.gov \\ 2 Department of Geology \& Geophysics, University of Alaska, P.O. Box 755780, Fairbanks, AK 99775-5780
}

\section{INTRODUCTION}

In 2012, the State of Alaska established its Strategic and Critical Minerals (SCM) Assessment project, a Statefunded Capital Improvement Project (CIP), to evaluate Alaska's statewide potential for SCM resources. The project is being implemented by the Alaska Division of Geological \& Geophysical Surveys (DGGS), and involves obtaining new airborne-geophysical, geological, and geochemical data.

For decades, the Ray Mountains area of west-central Alaska has been explored for its potential mineral resources. Investigations began in the 1970s, when results from the National Uranium Resource Evaluation (NURE) Hydrogeochemical and Stream Sediment Reconnaissance (HSSR) program reported anomalous concentrations of base metals, tin, tungsten, chromium, rare-earth elements (REEs) and uranium; the data from these programs are currently archived in the National Geochemical Database (Smith, 2006). The U.S. Bureau of Mines (USBM) later undertook several resource assessment programs in which bedrock and alluvial tin occurrences (Barker and Foley, 1986), bedrock chromite occurrences (Foley and McDermott, 1983), and alluvial REE occurrences (Barker, 1991) were located and described.

To further assess the rare-earth-element (REE) potential of the State-selected and top-filed lands in the Ray Mountains area, mineral-resource geologists at DGGS carried out a helicopter-supported geological and geochemical resource assessment spanning the Beaver, Bettles, Livengood, and Tanana quadrangles. Work was carried out between June 23 and August 5, 2012, to collect additional samples to be analyzed (Bachmann and others, 2013) and to re-analyze archived pulps of USBM samples (Blessington and others, 2013). The results of this work highlighted anomalously high heavy-REE concentrations in panned concentrate samples from No Name Creek gravels, as well as variability of REE concentrations in the source plutons, specifically the Fort Hamlin Hills pluton.

Consequently, the mineral-resource staff at DGGS undertook an additional resource assessment in the northern Fort Hamlin Hills area, part of the Bettles A-1 and A-6 quadrangles, from August 20 through 23, 2013, to augment the current geochemical data for the northern part of the Fort Hamlin Hills pluton (now designated the No Name Creek pluton) and to better understand the petrogenesis of the granites and their contribution to the potential alluvial REE resource.

Highlights of this project include identification and sampling in previously unmapped areas of the Fort Hamlin Hills, as well as the division of the Fort Hamlin Hills pluton into two physically independent plutons, the No Name Creek pluton to the north, and the Fort Hamlin Hills pluton to the south.

The text and analytical data and tables associated with this report are being released in digital format as .PDF and .CSV files, and are available from the DGGS website at no charge. 


\section{DOCUMENTATION OF METHODS}

\section{SAMPLE COLLECTION}

Rock samples were collected for two different purposes. Samples of visibly mineralized rock or those containing features associated with mineralization were preferentially collected and later analyzed for their trace-element geochemistry. Samples are typically "grab" samples, which were randomly collected at a location. Igneous and meta-igneous rocks showing minor alteration or weathering were collected for major-oxide, minor-oxide, and traceelement analyses to determine bulk rock compositions, or to identify the tectonic setting of a sample's protolith from petrogenetically important trace elements. Several fine-grained igneous and meta-igneous rocks were collected for "slab" X-ray fluorescence (slab XRF) petrographic analysis, which is a more cost-effective method of determining bulk rock composition for rocks that are fine-grained and have a uniform composition.

Location data were collected using Trimble Juno T41/5 WAAS-enabled GPS devices running ArcGIS for Windows Mobile. Data were merged into an ArcGIS geodatabase. WAAS-enabled GPS devices have a reported error of about $1 \mathrm{~m}$ (NSTB/WAAS T\&E Team, 2006); depending on degradation of the WAAS and GPS signals, the horizontal position error of sample locations in this report is in the range of 1 to 10 meters. Latitude and longitude are reported in the WGS 1984 datum.

\section{SAMPLE PREPARATION}

Rock samples were prepared by ALS Minerals in accordance with their PREP-31 package, which involves crushing the entire sample to greater than 70 percent passing -10 mesh $(2 \mathrm{~mm})$, then splitting off 250 grams and pulverizing the split to greater than 85 percent passing 75 microns. Prior to crushing, samples for whole-rock analyses were trimmed by DGGS staff to remove weathering, and cut surfaces were sanded to remove any saw metal. Rock samples that were collected for slab XRF analysis were cut into nominal 4-cm-diameter disks using a tile saw. The surfaces to be analyzed were polished to a smooth, uniform surface using 60 grit and 220 grit compound on a lap wheel.

\section{ANALYTICAL METHODS}

Samples were analyzed for a variety of major and trace elements and the full suite of rare-earth elements. In addition to ALS Minerals' internal quality-control program accredited to ISO/IEC 17025-2005 standards, DGGS monitored analysis quality by inserting one standard reference material with known compositions into the sample roster for every sample batch.

a. Trace-element compositions for rock samples were determined using four-acid digestion, followed by inductively coupled plasma-mass spectroscopy (ICP-MS) (ALS Minerals method ME-MS61, and ME-MS61r). Considering REEs may not be totally soluble in the aforementioned method, trace-element compositions were also determined using lithium metaborate fusion digestion, again followed by ICP-MS (ALS Minerals method ME-MS81).

b. For whole-rock geochemistry samples, major- and minor-oxides were analyzed by lithium metaborate fusion digestion and inductively coupled plasma-atomic absorption spectrometry (ICP-AES) (ALS Minerals method ME-ICP06). Trace elements, including rare-earth elements, were determined using lithium metaborate fusion digestion and ICP-MS (ALS Minerals method ME-MS81).

c. For slab XRF samples, polished sample slabs were directly analyzed using the PANalytical Axios wavelengthdispersive XRF and SuperQ ${ }^{\mathrm{TM}}$ software at the University of Alaska Fairbanks. $\mathrm{Nb}, \mathrm{Rb}, \mathrm{Sr}$, Y, and $\mathrm{Zr}$ were measured using the $37 \mathrm{mmRbSrYZr}$ analytical routine; other elements were measured with the IQ+37mmVac analytical routine. The $37 \mathrm{mmRbSrYZr}$ routine uses specific predetermined peak and background positions for which X-ray intensities are measured for 2-800 seconds (depending on the element). The intensity of the Rh Compton peak is used to estimate mass-absorption coefficients (MACs) for both unknowns and well- 
characterized natural standards. Peak intensities are computed and converted to concentrations using calibration curves employing at least ten natural rock standards. These procedures are routinely checked by analysis of secondary natural standards that were not em-ployed in making the calibration curves. Elemental abundances are typically within 2-5 percent of the amount present for concentrations greater than 10 times the detection limit; within 5-10 percent of the amount present for concentrations 4-10 times the detection limit, and within 30 percent of the amount present for concentrations near the detection limit. The IQ37 $\mathrm{mmVac}$ program scans over a series of energies corresponding to a range from $\mathrm{Ce} \mathrm{K}$-alpha to $\mathrm{O} \mathrm{K}$-alpha. Peak heights and backgrounds, and X-ray elemental interferences are picked with the software and checked manually to ensure quality control. Elemental abundances for all elements with atomic numbers between 8 and 92 are estimated from artificial standards; these estimations are used to calculate MACs for each element present above the detection limit. Revised concentrations are employed to calculate revised MACs until a stable solution is determined. The software is routinely checked using pressed pellets of well-characterized natural rock standards. Elemental abundances are within 1-2 percent of the amount present for major elements, 2-5 percent of the amount present for minor elements, and 5-10 percent of the amount present for trace elements.

For each sample, data tables contain either assay values or coded-value placeholders (null = not analyzed; $-1=$ the element's assay result is less than the lower detection limit for the method; $-2=$ the element's assay result is greater than the upper detection limit for the method). Detection limits for each of the reported elemental values obtained by the various methods are documented in the metadata file.

\section{ACKNOWLEDGMENTS}

Location data were, in part, prepared by Erik Bachmann. Geochemical analyses were assisted by Alicja Wypych.

\section{REFERENCES}

Bachmann, E.N., Blessington, M.J., Freeman, L.K., Newberry, R.J., Tuzzolino, A.L., Wright, T.C., and Wylie, William, 2013, Geochemical major-oxide, minor-oxide, trace-element, and rare-earth-element data from rocks and stream sediments collected in 2012 in the Ray Mountains area, Beaver, Bettles, Livengood, and Tanana quadrangles, Alaska: Alaska Division of Geological \& Geophysical Surveys Raw Data File 2013-5, 4 p. doi: $\underline{10.14509 / 25386}$

Barker, J.C., 1991, Investigation of tin-rare-earth-element placers in the Ray River watershed: U.S. Bureau of Mines Open-File Report 34-91, 63 p., 1 sheet, scale 1:63,360. http://dggs.alaska.gov/pubs/id/21385

Barker, J.C., and Foley, J.Y., 1986, Tin reconnaissance of the Kanuti and Hodzana rivers uplands, central Alaska: U.S. Bureau of Mines IC 9104, 27 p. http://dggs.alaska.gov/pubs/id/21287

Blessington, M.J., Reioux, D.A., and Werdon, M.B., 2013, Analyses of historic U.S. Bureau of Mines rock and heavy mineral concentrate samples for geochemical trace-element and rare-earth element data--Ray Mountains and Kanuti-Hodzana uplands area, Alaska: Alaska Division of Geological \& Geophysical Surveys Raw Data File 2013-7, 2 p. doi:10.14509/25581

Foley, J.Y., and McDermott, M.M., 1983, Podiform chromite occurrences in the Caribou Mountain and lower Kanuti River areas, central Alaska, Part I-Reconnaissance Investigations: U.S. Bureau of Mines IC 8915, 8 p., 1 sheet. http://dggs.alaska.gov/pubs/id/21279

NSTB/WAAS T\&E Team, 2006, Wide area augmentation system performance analysis report. Reporting period April 1 to June 30, 2006: FAA/William J. Hughes Technical Center, NSTB/WAAS T\&E Team, Atlantic City International Airport.

Smith, S.M., 2006, National geochemical database-Reformed data from the National Uranium Resource Evaluation (NURE) Hydrogeochemical and Stream Sediment Reconnaissance (HSSR) Program: U.S. Geological Survey Open-File Report 97-492, version 1.40. http://dggs.alaska.gov/pubs/id/21279 